\title{
Hubungan Retraksi Gigi Anterior dengan Bentuk Bibir pada Perawatan Protrusif Bimaksilar dengan Teknik Begg
}

\author{
Francisca Prima*, Prihandini Iman** dan Darmawan Sutantyo** \\ * Program Studi Ortodonsia PPDGS Fakultas Kedokteran Gigi Universitas Gadjah Mada \\ ** Bagian Ortodonsia, Fakultas Kedokteran Gigi Universitas Gadjah Mada \\ *J Denta No 1 Sekip Utara Yogyakarta;, e-mail: primasagita@googlemail.com
}

\begin{abstract}
ABSTRAK
Perubahan pada jaringan keras di daerah sepertiga wajah bagian bawah membawa perubahan pada jaringan lunak di atasnya. Pergerakan pada gigi anterior akan mempengaruhi bentuk bibir yang melekat langsung pada gigi. Penelitian ini bertujuan untuk mengetahui hubungan perubahanposisi gigi anterior dengan perubahan bentuk bibir atas dan bibir bawah setelah perawatan ortodontik pada maloklusi protrusif bimaksilar dengan teknik Begg pada orang dewasa Jawa. Penelitian dilakukan pada 17 pasang sefalogram lateral pasien berumur 18-35 tahun dengan protrusif bimaksilar sebelum dan sesudah perawatan. Masing-masing sefalogram diukur perubahan pada posisi gigi anterior yaitu jarak yang diukur dari tepi insisal gigi anterior ke garis referensi yang ditarik dari sella dan perubahan pada bibir atas dan bawah yaitu ketebalan dan panjang bibir. Data perubahan pada posisi gigi anterior dan perubahan pada bibir dianalisis dengan uji korelasi product moment Pearson dan analisis regresi. Hasilpenelitian menunjukkan bahwa terdapat korelasi bermakna antara perubahan posisi gigi anterior dengan perubahan ketebalan dan panjang bibir.Ketebalan bibir atas dan bibir bawah bertambah secara bermakna $(P<0,05)$. Panjang bibir atas dan bibir bawah juga bertambah secara bermakna $(P<0,05)$.Kesimpulan dari penelitian dijumpai bahwa retraksi gigi anterior atas dan bawah pada perawatan protrusif bimaksilar akan diikuti oleh pertambahan ketebalan dan panjang bibir atas dan bibir bawah.

Maj Ked Gi; Desember 2013; 20(2): 146 - 154.
\end{abstract}

Kata Kunci: Retraksi; Bimaksilar; Protrusif; Ketebalan; Panjang; Bibir

\begin{abstract}
The Relationship Between Anterior Teeth Retraction with The Lip Shape During Treatment on Bimaxillary Protrusion Using Begg Technique. The changes of hard tissue at the third lower area of the face affect the changes of the soft tissue. The movement of the anterior teeth influences lip shape which is in direct contact with these. This research aims to determine the relationship between the change of anterior teeth position and the change of upper and lower lips after orthodontic treatment on bimaxillary dental protrusion with Begg technique in adult Javanese. The research was conducted to 17 pairs of lateral setalogram on patients aged 18 to 35 with bimaxilar protrusion after and before treatment. Each setelogram measured the change of anterior teeth position (measured as the horizontal distance from the incisal tip to a constructed vertical to sella) and the change of upper and lower lips (measured as thickness and length of the lips). Data on anterior teeth position changes and lips changes were analysed using Pearson product moment correlation test and regression analysis. The result showed that there was a positive correlation between the change of anterior teeth position and the change in thickness and length of the upper and lower lips. The thickness of the upper and lower lips increased significantly $(p<0,05)$. The length of upper and lower lips increased significantly too $(p<0,05)$. Based on the research, it is concluded that treatment for on bimaxillary protrusion with Begg technique on the upper and lower anterior teeth retraction increases the thickness and length of upper and lower lips.

Maj Ked Gi; Desember 2013; 20(2): 146 - 154.
\end{abstract}

Keywords: Retraction; Bimaxillary; Protrusion; Length; Thickness; Lip

\section{PENDAHULUAN}

Motivasi utama pasien dalam menjalani perawatan ortodontik adalah keinginan untuk memperbaiki kondisi gigi geligi dan estetika wajah. Seorang ortodontis harus mengingat bahwa setiap perubahan pada hubungan gigi-geligi dapat menyebabkan berbagai efek pada kontur wajah. Ortodontis harus memperhatikan kemungkinan perubahan jaringan lunak karena retraksi gigi anterior sehingga dapat digunakan untuk merencanakan perawatan ortodontik bagi pasien dengan profil cembung. ${ }^{1}$ Perubahan yang terjadi terutama pada 
sepertiga wajah bagian bawah mengakibatkan perubahan pada area bibir, sudut nasolabial, sudut labiomental dan area sekitar dagu. ${ }^{2}$

Sebagian orang Indonesia mempunyai karakteristik wajah dengan protrusif bimaksilar, akan tetapi pengaruh perawatan ortodontik pada populasi orang Indonesia dengan protrusif bimaksilar hanya sedikit terdokumentasi. ${ }^{3}$ Protrusif bimaksilar dapat dirawat dengan perawatan ortodontik saja atau dapat juga dengan kombinasi osteotomi sub apikal anterior bimaksilar. ${ }^{4}$

Respon jaringan lunak terhadap retraksi gigi insisivus atas dan bawah pada kasus protrusif bimaksilar masih menjadi perdebatan. Terdapat keseragaman pemikiran bahwa perawatan ortodontik dapat mempengaruhi profil jaringan lunak, akan tetapi belum ada kesamaan mengenai seberapa banyak perubahan profil yang mengikuti retraksi gigi anterior. ${ }^{5}$ Literatur ortodontik sampai saat ini terpecah menjadi dua pemikiran. Sebagian peneliti menemukan tingginya korelasi retraksi gigi insisivus dengan mundurnya bibir atas sehingga terdapat hubungan erat antara perubahan jaringan keras dan perubahan jaringan lunak. Sebagian lain mengatakan bahwa perubahan pada jaringan lunak tidak selalu mengikuti perubahan pada gigigeliginya. ${ }^{6}$ Perbedaan ini berkaitan dengan variasi morfologi bibir, tonusitas bibir, dan posisi bibir (saat istirahat atau saat tertutup). ${ }^{7,4}$

Karakteristik protrusif bimaksilar yaitu adanya gigi-gigi yang protrusif pada kedua rahang dan adanya peningkatan kecembungan bibir.Kondisi ini sering ditemukan pada populasi etnis Afrika-Amerika dan juga etnis Asia, tetapi juga dapat ditemukan di setiap kelompok etnis. Adanya hubungan molar yang normal dengan overjet dan overbite yang relatif normal, memberi kesan harmonis dan seimbang. Adanya persepsi negatif pada masyarakat terhadap gigi dan bibir yang protrusif mendorong pasien dengan protrusif bimaksilar mencari perawatan ortodontik untuk mengurangi kecembungan wajah. Hal tersebut dapat dicapai dengan pencabutan gigi premolar untuk mendapatkan ruang bagi retraksi gigi-gigi anterior. ${ }^{8}$ Bibir atas pada umumnya hanya berkontak dengan gigi anterior atas sehingga pergerakannya dipengaruhi hanya oleh gigi anterior
atas.Pada kasus protrusif bimaksilar, bibir bawah hampir selalu berkontak dengan gigi anterior atas dan bawah, sehingga perubahannya tidak hanya dipengaruhi oleh gigi anterior bawah tetapi juga gigi anterior atas. ${ }^{9}$

Perawatan ortodontik dengan pencabutan pada protrusif bimaksilar bertujuan untuk mengurangi kecembungan pada sepertiga wajah bagian bawah, dan penuhnya bibir pada saat retraksi gigi anterior. ${ }^{3}$ Pada pencabutan keempat gigi premolar pertama dalam rangka memperbaiki kondisi bibir yang protrusif akan terjadi peningkatan besar sudut nasolabial sebesar $10^{\circ}$. Seiring dengan hal ini terjadi peningkatan panjang bibir atas hampir $2 \mathrm{~mm}$ dan peningkatan panjang bibir bawah hampir $1,5 \mathrm{~mm} .{ }^{4}$ Pada retraksi gigi insisivus atas dan bawah juga terjadi peningkatan ketebalan bibir atas setelah perawatan akan tetapi pada retraksi gigi insisivus bawah terjadi penurunan ketebalan bibir bawah. ${ }^{10}$

Pada bibir yang prominen, postur bibir terutama tergantung pada posisi gigi. Pada kondisi tersebut, retraksi pada gigi insisivus akan berefek pada fungsi bibir maupun prominensi bibir. Posisi bibir juga dipengaruhi oleh posisi dan inklinasi gigi insisivus atas dan bawah sebagai hasil dari perawatan ortodontik menurut Ghany." Posisi insisivus mandibula menentukan posisi dan postur bibir bawah menurut Kusnoto. ${ }^{3}$ Terdapat hubungan bermakna antara retraksi gigi insisivus dengan posisi Labrale Superius, dimana terjadi retraksi bibir sebesar $1 \mathrm{~mm}$ setiap retraksi gigi insisivus sebesar $3,8 \mathrm{~mm}$. ${ }^{1}$

Perubahan pada jaringan lunak setelah perawatan dengan alat cekat Edgewise, alat cekat Begg ,dan dengan alat fungsional beberapa telah dilaporkan. Alat cekat teknik Begg dengan kontrol anchorage yang baik, dimana seluruh kekuatan anchorage berasal dari intra oral, memberikan hasil perawatan yang sangat baik pada kasus protrusif bimaksilar. Bite opening atau pembukaan gigitan pada perawatan ortodontik dengan teknik Begg adalah hal yang sangat penting tidak hanya dalam meminimalkan berbagai hambatan dalam koreksi protrusi, tetapi juga mencegah retraksi insisivus atas terhadap insisivus bawah sehingga penting untuk mempertahankan bite opening selama proses retraksi dilakukan. Penggunaan elastik intermaksiler 
dan intramaksiler dengan kekuatan ringan dapat memaksimalkan kemampuan intrusi anchorage bends dan juga secara efektif memaksimalkan kontrol anchorage molar. ${ }^{4}$

Alat cekat teknik Begg adalah salah satu teknik perawatan ortodontik dengan retraksi gigi insisivus yang menghasilkan gerakan tipping mahkota gigi insisivus ke posterior dan apeks gigi insisivus ke arah anterior. Gerakan tipping tersebut dikoreksi dengan palatal root torque (uprighting) pada tahap III yang menghasilkan gaya ke arah palatal sehingga menyebabkan apeks gigi insisivus maksila bergerak ke posterior dan permukaan insisal bergerak ke anterior. $^{12}$

Penelitian ini bertujuan untuk mengetahui hubungan retraksi gigi anterior dengan perubahan ketebalan dan panjang bibir atas dan bibir bawah pada perawatan maloklusi Angle kelas I Protrusif Bimaksilar dengan teknik Begg pada kasus pencabutan empat gigi premolar pertama pada analisis sefalogram lateral.

\section{METODOLOGI PENELITIAN}

Subyek penelitian adalah pasien yang telah selesai dirawat ortodontik di klinik OrtodonsiaProgram Pendidikan Dokter Gigi Spesialis Fakultas Kedokteran Gigi Universitas Gadjah Mada Yogyakarta periode 2006-20012, dengan kriteria sebagai berikut: 1) dirawat dengan alat cekat Teknik Begg; 2) kasus maloklusi Angle kelas I protrusif bimaksilar; 3) pencabutan keempat gigi premolar pertama; 4) tidak ada gigi yang hilang secara kongenital (kecuali M3); 5) tidak digunakan prosedur bedah ortognatik ; 6) usia 18-35 tahun; 7) telah selesaiperawatan .

Obyek penelitian adalah sefalogram lateral sebelum dan setelah perawatan ortodontik didapatkan dari pasien yang memenuhi kriteria pemilihan subyek penelitian. Alat yang digunakan dalam penelitian 1) kertas asetat ; 2) pensil $4 \mathrm{H}$; 3) illuminator; 4) jangka sorong; 5) protraktor. Penapakan sefalogram dan pengukuran sebanyak

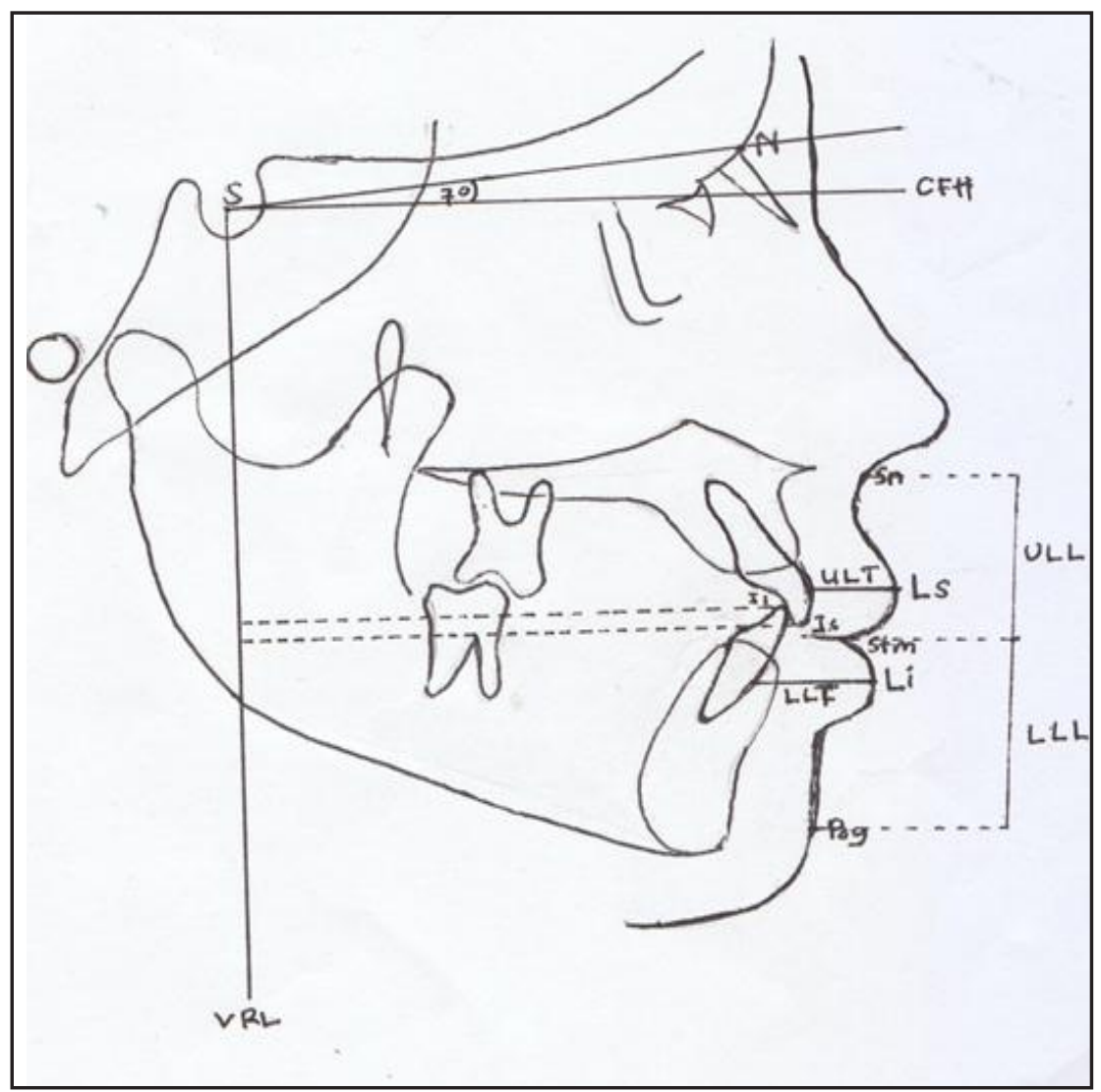

Gambar 1. Titik dan garis referensi 
dua kali oleh peneliti.Hasil dari dua pengukuran dibandingkan. Jika nilainya sama atau kurang dari 0,5 mm untuk pengukuran linear maka dihitung reratanya. Penapakan dan pengukuran ketiga dilakukan jika perbedaan hasil kedua pengukuran linear lebih besar dari 0,5 mm. Hasilnya dibandingkan dengan kedua nilai sebelumnya kemudian nilai rerata ditentukan dari dua nilai yang terdekat. ${ }^{4}$ Bidang dan titik referensi yang digunakan adalah $\mathrm{S}$ : sella; $\mathrm{N}$ : nasion; Ls:bibir atas ; Li: bibir bawah; Sn: subnasal; Pog: pogonion ; Stm : stomion CFH: Constructed Franfurt Horizontal ; VRL: Vertical Reference Line (Gambar 1)

Analisa statistik dengan menggunakan rata-rata dan standard deviasi digunakan untuk memperlihatkan perbedaan nilai antara sebelum dan sesudah perawatan. Uji korelasi product moment Pearson digunakan untukmengetahui adanya hubungan antara retraksi inisisivus dengan perubahan jaringan lunak bibir.Sedangkan analisis regresi digunakan untuk mengevaluasi prediksi perubahan jaringan lunak bibir setelah retraksi gigi anterior.

\section{HASIL PENELITIAN}

Analisa hasil perawatan (Tabel 1) memperlihatkan baik pada tepi insisal gigi anterior atas maupun bawah terjadi retraksi secara bermakna $(p<0,01)$. Terjadi retraksi sebesar $4 \pm 3.2 \mathrm{~mm}$ pada gigi insisivus atas dan $4.2 \pm 3.3 \mathrm{~mm}$ pada gigi insisivus bawah.Adanya retraksi gigi inisisivus atas dan bawah menyebabkan peningkatan ketebalan bibir atas secara bermakna $(r=0.63, p<0,05)$ dan bibir bawah juga bermakna $(r=0,68), p<0,05)$. Panjang bibir atas juga bertambah secara bermakna $(r=0.67, p<0,05)$, demikian juga pada bibir bawah bertambah panjang secara bermakna $(r=0.61, p<0,05)$

Tabel 1. Rerata dan simpangan baku retraksi insisivus atas dan bawah, ketebalan dan panjang bibir atas dan bawah sebelum dan sesudah perawatan

\begin{tabular}{cllccc}
\hline No & Variabel & Titik referensi & \multicolumn{1}{c}{ Sebelum } & \multicolumn{1}{c}{ Sesudah } & \multicolumn{1}{c}{ Perubahan } \\
\hline 1 & Retraksi I atas & Is-VRL & $68,00 \pm 6,30$ & $64,00 \pm 5,30$ & $-4,00 \pm 3,20$ \\
2 & Retraksi I bawah & li-VRL & $64,60 \pm 6,90$ & $60,40 \pm 5,80$ & $-4,20 \pm 3,30$ \\
3 & Tebal bibir atas & Ls-Ls' & $9,33 \pm 1,54$ & $10,60 \pm 1,84$ & $1,27 \pm 0,30$ \\
4 & Tebal bibir bawah & Li-Li' & $10,20 \pm 0,23$ & $11,70 \pm 1,89$ & $1,05 \pm 1,66$ \\
5 & Panjang bibir atas & Sn-Stm & $22,67 \pm 3,57$ & $24,73 \pm 3,05$ & $2,07 \pm 0,52$ \\
6 & Panjang bibir bawah & Stm-Pog & $44,67 \pm 4,16$ & $48,53 \pm 4,68$ & $3,86 \pm 0,52$ \\
\hline
\end{tabular}

Tabel 2. Hasil analisis korelasi product momentPearson antara variabel bebas dan variabel terikat

\begin{tabular}{llcc}
\hline Variabel & N & Koefissien korelasi $(r)$ & $P$ \\
\hline Retraksi I atas dan tebal bibir atas & 17 & 0,629 & $0,008 *$ \\
Retraksi I atas dan panjang bbir bawah & 17 & 0,675 & $0,001 *$ \\
Retraksi I bawah dan tebal bibir bawah & 17 & 0,683 & $0,002 *$ \\
Retraksi I bawah dan panjang bibir bawah & 17 & 0,613 & $0,037 *$ \\
\hline
\end{tabular}

\section{Keterangan :}

P : tingkat kemaknaan ;

* : bermakna bila $\mathrm{p}<0,05$ 


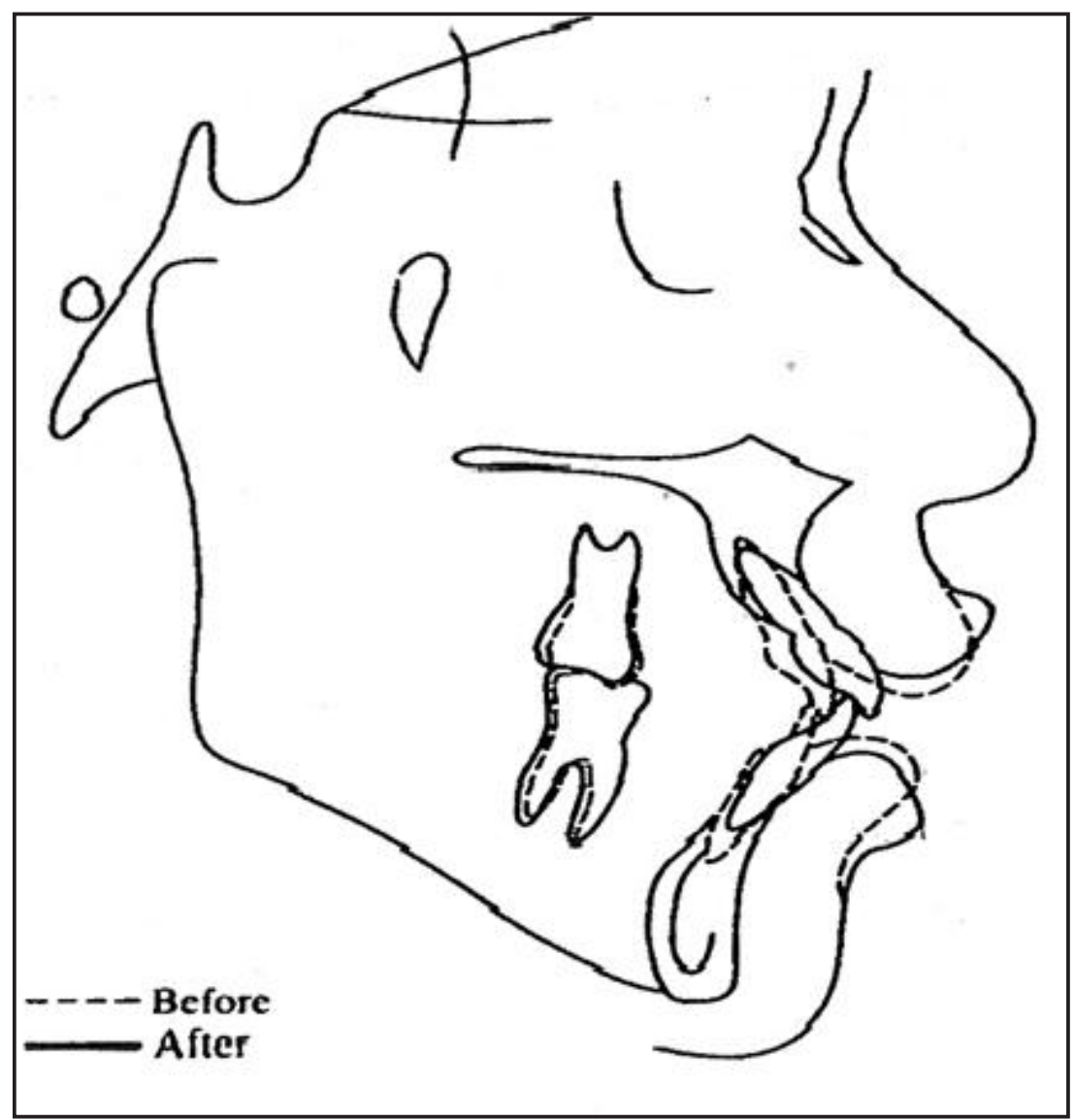

Gambar 2. Superimpose perubahan bentuk bibir sebelum dan setelah perawatan

\section{PEMBAHASAN}

Hasil perawatan kasus maloklusi Angle kelas I Protrusif Bimaksilar dengan pencabutan empat gigi premolar pertama dengan teknik Begg pada subjek dengan rentang umur 18-35 tahun yang diukur secara linear seperti terlihat pada tabel 1 menunjukkan bahwa posisi gigi inisisivus atas dan posisi gigi insisivus bawah dari 17 pasang sampel keseluruhan mengalami perubahan ke posterior dengan rerata perubahan sebesar 4,00 $\pm 3,2 \mathrm{~mm}$ pada insisivus atas dan 4,20 $\pm 3,30 \mathrm{~mm}$ pada insisivus bawah. Hal ini dapat diasumsikan bahwa pada perawatan maloklusi Angle kelas Protrusif Bimaksilar yang memerlukan pencabutan empat gigi premolar pertama dengan teknik Begg terjadi retraksi gigi insisivus atas dan retraksi inisisivus bawah. Pemakaian elastik intermaksiler kelas II selain mengakibatkan retraksi pada gigi anterior atas juga akan mengakibatkan retraksi pada gigi anterior bawah sehingga tercapai relasi edge to edge. ${ }^{7}$ Hasil yang didapat sesuai dengan penelitian yang dilakukan oleh Lew, ${ }^{13}$ setelah perawatan kasus kelas 1 dapat ditemukan adanya perubahan pada inklinasi gigi insisivus atas dan bawah. Perubahan posisi gigi inisisivus dapat diakibatkan karena perawatan ortodontik. Salah satu keistimewaan teknik Begg adalah kemampuan untuk mengurangi overbite dengan anchorage bendpada kawat busur dan overjet dengan pemakaian elastik kelas II.9,3

Mengenai ketebalan bibir, tebal bibir atas secara linear pada 17 pasang sampel keseluruhan mengalami peningkatan dengan rerata 1,27 $\pm 0,30 \mathrm{~mm}$ dan pada bibir bawah mengalami peningkatan dengan rerata 1,05 $\pm 1,66 \mathrm{~mm}$. Hal ini dapat diasumsikan bahwa pada perawatan maloklusi Angle kelas I Protrusif Bimaksilar dengan pencabutan empat gigi premolar pertama dengan teknik Begg terjadi retraksi bibir atas dan retraksi bibir bawah. Retraksi 
bibir atas terjadi akibat retraksi gigi inisisivus atas, demikian juga pada bibir bawah dimana retraksi bibir bawah terjadi akibat retraksi gigi inisisivus bawah. ${ }^{4}$ Peningkatan ketebalan bibir atas dan bibir bawah sebesar berkaitan dengan inklinasi gigi insisivus atas dan bawah ke arah lingual pada saat retraksi gigi anterior dengan menggunakan teknik Begg. Penelitian yang dilakukan oleh Kinney dan Harris membandingkan perawatan ortodontik dengan teknik Begg, Edgewise dan Straightwire, mengatakan bahwa pada teknik Begg lebih banyak terjadi lingual tipping mahkota gigi insisivus atas dibanding dua teknik yang lainnya (sekitar $8,5^{\circ}$ dibanding $\left.1,8^{\circ}\right),{ }^{10}$ hal ini menyebabkan inklinasi gigi insisivus menjadi lebih tegak pada akhir perawatan. Pada perawatan maloklusi kelas I Protrusif Bimaksilar dengan alat cekat teknik Begg akan merubah posisi gigi insisivus atas dan bawah menjadi lebih ke palatal dan lingual karena tipping pada tahap retraksi anterior, serta merubah inklinasi gigi insisivus atas dan bawah pada akhir perawatan menjadi lebih tegak. Besar sudut nasolabial dan labiomental akan meningkat seiring dengan mundurnya bibir atas dan bawah yang disebabkan oleh mundurnya gigi insisivus atas dan bawah dan lebih tegaknya gigi insisivus atas dan bawah. Peningkatan ketebalan bibir pada bibir atas dan bibir bawah senada dengan beberapa penelitian sebelumnya. ${ }^{12}$

Panjang bibir atas dan panjang bibir bawah pada 17 pasang sampel keseluruhan mengalami peningkatan dengan rerata panjang bibir atas sebesar 2,07 $\pm 0,52 \mathrm{~mm}$ dan rerata panjang bibir bawah sebesar $3,86 \pm 0,52 \mathrm{~mm}$. Hal ini dapat diasumsikan bahwa pada perawatan kasus maloklusi Angle kelas I Protrusif Bimaksilar dengan pencabutan empat gigi premolar pertama dengan teknik Begg terjadi perubahan tinggi muka bagian bawah. Elastik intermaksiler kelas II yang digunakan pada koreksi maloklusi akan mengakibatkan rotasi bidang oklusal dan mandibula berlawanan arah jarum jam (counter clockwise rotation). Posisi mandibula yang bergerak ke posterior berarti bahwa terjadi rotasi mandibula searah jarum jam yang menyebabkan perubahan pada tinggi muka bagian bawah. Posisi mandibula yang mengalami perubahan ke posterior diakibatkan karena adanya perbedaan antara komponen dental dan komponen skeletal, selain disebabkan oleh komponen dental, maloklusi dapat disebabkan karena malrelasi komponen skeletal (skeletal kelas 1). ${ }^{5}$ Peningkatan serupa juga terjadi pada penelitian ${ }^{14}$ sebesar $1,1 \mathrm{~mm}$ pada bibir atasdan 1,5 mm pada bibir bawah pada perempuan berumur 7-18 tahun. Perubahan bermakna yang ditemukan pada penelitian ini terutama pada bibir bawah kemungkinan terjadi karena lebih panjangnya bibir bawah sebelum perawatan, makin banyaknya mahkota inisisivus atas yang ditutupi oleh bibir bawah sebelum perawatan, makin besarnya panjang muka bagian bawah karena perawatan ortodontik. ${ }^{14}$ Hal ini senada dengan penelitian Ghany dimana pertambahan panjang bibir atas secara bermakna erat korelasinya dengan perubahan inklinasi gigi insisivus atas. ${ }^{5}$

Berdasarkan analisis korelasi product moment Pearson terdapat hubungan positif antara retraksi gigi insisivus atas dengan ketebalan bibir atas. Hal ini berarti hipotesis yang menyatakan terdapat hubungan positif antara retraksi gigi insisivus atas dan tebal bibir atas, semakin mundur gigi insisivus atas maka semakin tebal bibir atas diterima. Retraksi gigi insisivus atas akan mengakibatkan retraksi pada bibir atas, apabila bibir atas bergerak ke posterior maka kontur bibir atasakan berkurang. Bertambah tebalnya bibir atas pada saat retraksi gigi inisisivus atas kemungkinan dipengaruhi oleh perlekatan bibir atas dengan hidung.

Berdasarkan analisis korelasi product moment Pearson terdapat hubungan positif antara retraksi gigi insisivus atas dengan panjang bibir atas. Hal ini berarti hipotesis yang menyatakan terdapat hubungan positif antara retraksi gigi insisivus atas dan tebal bibir atas, semakin mundur gigi insisivus atas maka semakin panjang bibir atas diterima. Retraksi gigi insisivus atas akan mengakibatkan perubahan perlekatan hidung dengan bibir atas pada daerah subnasal. Pertambahan panjang bibir atas pada saat retraksi gigi inisisivus atas kemungkinan dipengaruhi perubahan inklinasi gigi insisivus atas dan perlekatan bibir atas dan hidung. Bentuk bibir atas juga didukung oleh bibir bawah. Perubahan bibir bawah pada saat retraksi akan mengakibatkan bertambah panjangnya bibir atas. ${ }^{2}$ 
Berdasarkan analisis korelasi product moment Pearson terdapat hubungan positif antara retraksi gigi insisivus bawah dengan ketebalan bibir bawah. $\mathrm{Hal}$ ini berarti hipotesis yang menyatakan terdapat hubungan positif antara retraksi gigi insisivus bawah dan tebal bibir bawah, semakin mundur gigi insisivus bawah maka semakin tebal bibir bawah diterima. Retraksi gigi insisivus bawahakan mengakibatkan retraksi pada bibir bawah, apabila bibir bawah bergerak ke posterior maka kontur bibirbawah akan berkurang. Bertambah tebalnya bibir bawah pada saat retraksi gigi inisisivus atas kemungkinan dipengaruhi oleh perubahan inklinasi gigi insisivus bawah yang menjadi lebih tegak pada akhir perawatan dengan teknik Begg.

Berdasarkan analisis korelasi product moment Pearson terdapat hubungan positif antara retraksi gigi insisivus bawah dengan panjang bibir bawah. Hal ini berarti hipotesis yang menyatakan terdapat hubungan positif antara retraksi gigi insisivus bawah dan panjang bibir bawah, semakin mundur gigi insisivus bawah maka semakin panjang bibir bawah diterima. Retraksi gigi insisivus bawahakan mengakibatkan retraksi pada bibir bawah, apabila bibir atas bergerak ke posterior maka kontur bibir bawah akan berkurang. Pertambahan panjang bibir bawah pada saat retraksi gigi inisisivus bawah kemungkinan dipengaruhi oleh perubahan tinggi muka bagian bawah karena perubahan posisi mandibula yang lebih ke posterior.

Analisis regresi digunakan untuk menguji kemaknaan hubungan antara perubahan posisi gigi anterior sebagai variabel prediktor dan perubahan bentuk bibir sebagai variabel yang diprediksi. Perubahan posisi insisivus atas memiliki pengaruh yang signifikan $(p<0,05)$ terhadap perubahan ketebalan bibir atas dengan persamaan $Y=a+b x$. Nilai konstanta (a) adalah 0,760 dan konstanta b adalah 1,583, maka dapat disimpulkan setiap retraksi $1 \mathrm{~mm}$ gigi insisivus atas akan mengakibatkan pertambahan tebal bibir atas sebesar $2,343 \mathrm{~mm}$, sehingga dapat diperoleh perbandingan antara retraksi gigi insisivus atas dengan tebal bibir atas sebesar 1: 2,343. Hasil penelitian ini memiliki pola yang sama dengan penelitian yang dilakukan oleh Ghany ${ }^{5}$ yang menyatakan bahwa gigi insisivus atas merupakan variabel jaringan keras yang dapat digunakan sebagai prediktor yang dapat menjelaskan terjadinya respon bibir atas akibat perawatan ortodontik. Perbandingan antara retraksi gigi inisisvus atas dengan perubahan ketebalan bibir atas diperoleh rasio sebesar $1: 2,343$

Analisis regresi digunakan untuk menguji kemaknaan hubungan antara perubahan posisi gigi insisivus atas sebagai variabel prediktor dan perubahan panjang bibir atas sebagai variabel yang diprediksi. Perubahan posisi insisivus atas memiliki pengaruh yang signifikan $(p<0,05)$ terhadap perubahan panjang bibir atas dengan persamaan $\mathrm{Y}=\mathrm{a}+\mathrm{bx}$. Nilai konstanta (a) adalah 0,425 dan konstanta $b$ adalah 1,242, maka dapat disimpulkan setiap retraksi $1 \mathrm{~mm}$ gigi insisivus atas akan mengakibatkan pertambahan panjang bibir atas sebesar 1,667 mm, sehingga dapat diperoleh perbandingan antara retraksi gigi insisivus atas dengan panjang bibir atas sebesar 1:1,667. Hasil penelitian ini memiliki pola yang sama dengan penelitian yang dilakukan oleh Chany, ${ }^{5}$ yang menyatakan bahwa gigi insisivus atas merupakan variabel jaringan keras yang dapat digunakan sebagai prediktor yang dapat menjelaskan terjadinya respon bibir atas akibat perawatan ortodontik. Perbandingan antara retraksi gigi inisisvus atas dengan perubahan panjang bibir atas diperoleh rasio sebesar 1,667

Analisis regresi digunakan untuk menguji kemaknaan hubungan antara perubahan posisi gigi insisivus bawah sebagai variabel prediktor dan perubahan tebal bibir bawah sebagai variabel yang diprediksi. Perubahan posisi insisivus bawah memiliki pengaruh yang signifikan $(p<0,05)$ terhadap perubahan tebal bibir bawah dengan persamaan $\mathrm{Y}=$ a+bx. Nilai konstanta (a) adalah 1,263 dan kontanta b adalah 1,017, maka dapat disimpulkan setiap retraksi $1 \mathrm{~mm}$ gigi insisivus bawah akan mengakibatkan pertambahan tebal bibir bawah sebesar 2,280 mm, sehingga dapat diperoleh perbandingan antara retraksi gigi insisivus bawah dengan tebal bibir bawah sebesar 1:2,280. Hasil penelitian ini memiliki pola yang sama dengan penelitian yang dilakukan oleh Chany, ${ }^{5}$ yang menyatakan bahwa gigi insisivus bawah merupakan variabel jaringan keras yang dapat digunakan sebagai prediktor yang dapat 
menjelaskan terjadinya respon bibir bawah akibat perawatan ortodontik. Perbandingan antara retraksi gigi inisisvus bawah dengan perubahan tebal bibir bawah diperoleh rasio sebesar $1: 2,280$

Analisis regresi digunakan untuk menguji kemaknaan hubungan antara perubahan posisi gigi insisivus bawah sebagai variabel prediktor dan perubahan panjang bibir bawah sebagai variabel yang diprediksi. Perubahan posisi insisivus bawah memiliki pengaruh yang signifikan $(p<0,05)$ terhadap perubahan panjang bibir bawah dengan persamaan $\mathrm{Y}=\mathrm{a}+\mathrm{bx}$. Nilai konstanta (a) adalah 0,217 dan kontanta b adalah 1,409 maka dapat disimpulkan setiap retraksi $1 \mathrm{~mm}$ gigi insisivus bawah akan mengakibatkan pertambahan panjang bibir bawah sebesar 1,626 mm, sehingga dapat diperoleh perbandingan antara retraksi gigi insisivus bawah dengan panjang bibir bawah sebesar 1:1,626. Hasil penelitian ini memiliki pola yang sama dengan penelitian yang dilakukan oleh Roos dan Nilss ${ }^{15}$ yang menyatakan bahwa gigi insisivus bawah merupakan variabel jaringan keras yang dapat digunakan sebagai prediktor yang dapat menjelaskan terjadinya respon bibir bawah akibat perawatan ortodontik.

\section{KESIMPULAN}

Penelitian mengenai hubungan antara retraksi gigi anterior dengan perubahan bentuk bibir pada perawatan kasus maloklusi Angle kelas I Protrusif Bimaksilar yang dilakukan pencabutan empat gigi premolar pertama dengan teknik Begg, dapat diambil kesimpulan sebagai berikut :1) Terdapat hubungan positif antara perubahan posisi gigi insisivus atas dan ketebalan bibir atas. Semakin mundur posisi gigi insisivus atas maka semakin tebal bibir atas. Perbandingan antara retraksi gigi insisivus atas dengan tebal bibir atas sebesar $1: 2,343 ; 2$ ) Terdapat hubungan positif antara perubahan posisi gigi insisivus atas dan panjang bibir atas. Semakin mundur posisi gigi insisivus atas maka semakin panjang bibir atas. Perbandingan antara retraksi gigi insisivus atas dengan panjang bibir atas sebesar 1: 1,667. 3) Terdapat hubungan positif antara perubahan posisi gigi insisivus bawah dan tebal bibir bawah. Semakin mundur posisi gigi insisivus bawah maka semakin tebal bibir bawah. Perbandingan antara retraksi gigi insisivus bawah dengan tebal bibir bawah sebesar 1: 2,280. 4)Terdapat hubungan positif antara perubahan posisi gigi insisivus bawah dan panjang bibir bawah. Semakin mundur posisi gigi insisivus bawah maka semakin panjang bibir bawah. Perbandingan antara retraksi gigi insisivus bawah dengan panjangbibir bawah sebesar 1: 1,626

\section{DAFTAR PUSTAKA}

1. Roos dan Nilss. Soft tissue profile changes in class II treatment. Am J Orthod. 1977; 72 (2): 165-175.

2. Jamilian A. Cholami D. Toliat M. Safaeian S. Changes in facial profile during orthodontic treatment with extraction of four first premolars. Orthodontic Waves. 2008; 67: 157-161

3. Kuftine MM, Glass RL. Stability of the IMPA with reference to the begg method. Angle Orthod. 1971; 41 (4): $264-70$

4. Kusnoto J, Kusnoto $\mathrm{H}$. The effect of anterior tooth retraction on lip position of orthodontically treated adult Indonesians. Am. J. Orthod dentofacial Orthop. 2001;120: 304-7

5. Ghany AHA. Soft tissue profile changes associated with treatment of anterior open bite. Cairo. Dent J. 2008; vol 24 (1) : 85-97.

6. Caplan MJ, Shivapuja PK. The Effect of premolar extractions on the soft tissue profile in adult African American females. Angle Orthod. 1997; 67 (2) : 129136.

7. Fletcher GGT. The Begg Appliance and Technique. Bristol : Wright PSG; 1981. H. 1-30, 49-71.

8. Kusnoto $H$. Soft tissue profile changes after orthodontic treatment in class III malocclusion. Jurnal PDGI. 1994; 43 (1): 72-81.

9. Begg PR, Kesling PC. Begg orthodontic theory and technique. Ed 3. Philadelphia : WB Saunders Company; 1977.hal. 127-50.

10. Mc. Kinney JR, Harris EF. Influence of patient age and sex on orthodontic treatment : Evaluation of Begg lightwire, standard Edgewise, and Straightwire techniques. Am. J. Orthod. Dentofac. Orthop. 2001; $120: 530-41$. 
11. Garner LD. Soft tissue changes concurrent with orthodontic tooth movement. Am J Orthod. 1974; 66 (4) : 367-77.

12. Diels RM, Kalra V, DeLoach Jr N, Powers M, Nelson SS. Changes in soft tissue profile of African American following extraction treatment. Angle Orthod. 1980; 65(4): 285-292.

12. Nanda RS, Meng H, Kapila S, Goorhuis J. Growth changes in the soft tissue facial profile. Angle Orthod. 1990; 60: 177-190.
13. Lew K. Profile changes following orthodontic treatment of bimaxillary protrusion in adults with the begg appliance. European Journal of Orthod. 1989; 11: 375-381.

14. Waldman $\mathrm{BH}$. Change in lip contour with maxillary incisor retraction. Angle Orthod. 1982; 52(2): 129-34. 